\title{
REACTIVE OXYGEN AND NITROGEN SPECIES ROLE IN EXPERIMENTAL PERIODONTITIS DEVELOPMENT
}

\author{
A. Ye. Demkovych \\ I. HORBACHEVSKY TERNOPIL STATE MEDICAL UNIVERSITY, TERNOPIL, UKRAINE
}

Introduction. Activation of lipid peroxidation is one of the trigger mechanisms of periodontium injury, which is primary caused by cellular damage. Reactive oxygen and nitrogen species (RONS) are able to cause damage to a cell as well as final products of lipid peroxidation, including unsaturated aldehydes and other metabolites.

Objective. The aim of the research was to determine the role of RONS and accumulation of lipid peroxidation derivatives in initial development and formation of chronical inflammatory process in periodontium.

Methods. Experimental periodontitis was modeled in animals by injection of complex mixtures of microorganisms diluted in egg protein into periodontal tissues. The results of biochemical studies of free radical processes activity in blood serum were evaluated by content of diene, triene conjugates, TBA-active products and total quantity of metabolites of nitric oxide $\left(\mathrm{NO}_{2}{ }^{-}+\mathrm{NO}_{3}{ }^{-}\right)$, which were determined on the $7^{\text {th }}, 14^{\text {th }}$ and $30^{\text {th }}$ days of the experiment.

Results. Generation of active forms of oxygen is more influential, providing longevity of inflammatory process. This pays attention to typical dynamics of changes in active processes of lipid peroxidation in the development and course of experimental periodontitis. The study of inflammatory process with a bacterial-immune component in the rats' periodontal complex proved accumulation of lipid peroxidation and nitric oxide metabolites in blood serum.

Conclusions. The preservation of increased lipid peroxidation and nitric oxide metabolites in blood serum of the experimental animals with acute periodontitis conduce enhance of alteration and delayed healing that result in its sequel into chronical periodontitis.

KeY Wo Rd S: periodontitis; nitric oxide metabolites; TBA-active products; diene conjugates; triene conjugates.

\section{Introduction}

Improvement of the established and creation of new methods of generalized periodontitis treatment is one of the urgent matters of contemporary dentistry $[1,2]$. inflammatory processes in the complex of periodontal tissues are the most common among inflammatory complications of maxillofacial area $[3,4]$. it is indisputable that pathogenic infection is crucial in this case, as well as their combinations, in particular Staphylococcus and Streptococcus, which develop in cases of reduced resistance of oral tissues to infectious agents. $[5,6]$. The etiology and pathogenesis of periodontal diseases are complicated and studied insufficiently however, the infectious factor and ability of immune protective mechanisms (local cellular unspecifi

Corresponding author: Andriy Demkovych, Department of Orthopedic Dentistry, I. Horbachevsky Ternopil State Medical University, 1 Maydan Voli, Ternopil, 46001, Ukraine

E-mail: demkovushae@tdmu.edu.ua

Phone number: +380979342501 and general adaptive) are essential; the features of pathological process development, its subsequent treatment and prophylaxis affects depend on them [7]. It is unclear as well as the mechanisms, due to which different by nature and character of action local and general factors lead to inflammatory and destructive lesions of periodontal tissues [8]. The investigation of inflammatory process mechanisms in the tissues of periodontal complex is one of the current issues of contemporary dentistry due to a relatively wide spread and unfavorable prognosis, because the frequency of periodontal disease in world is within 5-20\% and increases with age up to $75 \%[9,10]$.

the development of inflammatory-destru tive changes in periodontal tissues is caused by disturbances of microcirculation and transcapillary exchange with underlying severe hypoxia. activation of reactive oxygen and nitrogen species (Ron S) and exhaustion of antioxidant defense in biological tissues is the most serious of all effects and outcomes of 
hypoxia. activation of lipid peroxidation (I Po) is a trigger mechanism for oxidative stress with cellular metabolism disorders, which are primary caused by damage of cellular and subcellular membranes [11].

activation of I Po and decrease of antioxidant protection contribute to accumulation of deleterious free cholesterol, lysophosphatides, phosphatidylcholine, that changes the dynamic stability of cellular membranes due to pathological process development in periodontal complex [13].

all these facts about the influence of oxidative stress on the pathogenesis of periodontitis are present in the activity of lipid peroxidation as potential predictors of escalation of inflammatory lesions in periodontal disease. the disturbance of antioxidant protection in the patients with hypertension, which was proved by changes in the activity of catalase, ceruloplasmin and saturation of transferrin by iron, and the increase in the level of diene conjugates and TBA-active products in serum, which leads to the development of endogenous intoxication syndrome in the patients with general periodontitis. One of the parameters that allow estimating the state of free radical processes is the content of lipids hydroperoxides and $\mathrm{t} \mathrm{Ba}$-active products formed by oxidation of unsaturated fatty acids, and aldehyde and ketone derivatives, which are developed by the action of active radicals on the amino acid residues in protein molecules [14].

the components of bacterial toxins (especially lipopolysaccharide) and proinfla matory cytokines (mainly tnf - $a$, il -1 and interferon gamma-ifn -y) produced by the affected tissues stimulate the production of nitric oxide (no ) by the inducible nitric oxide synthase (ino $S$ ) in different cell types [15]. It is proved that parodonotopathogenic bacteria are capable of inducing NO formation by inducible NO synthase. excessive no formation, which occurs when ino $S$ is stimulated by proinflammatory cytokines and endotoxins of pathogenic microfl ra of oral cavity, leads to nitrooxidative stress which, together with the activation of lipoperoxidation and oxidative modification of proteins, can cause increased disintegration of connective tissue components and progressing of periodontitis [16].

The aim of this investigation was to determinate the pathogenic influence of Ron $\mathrm{S}$ and accumulation of lipid peroxidation derivatives in regard to initial development and formation of chronical inflammatory process in periodontal complex.

\section{Methods}

the experiments were carried out using white clinical healthy male rats, $150-200 \mathrm{~g}$ in weight, in environments of vivarium, on a standard diet balanced for the basic elements. The research related to animals' use has been complied with all the relevant national regulations and institutional policies for the care and use of animals. The investigations was conducted following the general rules and regulations of the European Convention for the Protection of vertebrate Animals Used for experimental and other Scientific Purposes (Strasbourg, 1986), the General Ethics on animal experimentation (Kyiv, 2001).

the experimental animals were randomly selected and divided into 4 groups: the $1^{\text {st }}-$ intact animal, controls $(n=10)$; the $2^{\text {nd }}$ - animals with experimental periodontitis on the $7^{\text {th }}$ day of study $(n=8)$; the $3^{\text {rd }}$ - animals with experimental periodontitis on the $14^{\text {th }}$ day of study $(n=8)$; the $4^{\text {th }}$ - animals with experimental periodontitis on the $30^{\text {th }}$ day of study $(n=8)$. experimental periodontitis (EP) was caused by introduction of complex mixtures of microorganisms diluted in egg protein into periodontal tissues [17]. Simultaneously with the injections of the pathogen a complete Freund's adjuvant was injected in the rat paw to enhance the immune response. When conducting studies with animals of group 4 , on the $14^{\text {th }}$ day, repeated administration of the pathogen and injection of adjuvant was carried out. At the $7^{\text {th }}$ and $14^{\text {th }}$ days the experimental animals were euthanized by total heart bloodletting and previous thiopental anesthesia. Serum samples were taken for further research.

In blood serum the level of diene (DC) and triene conjugates (TC), TBA-active products and total quantity of metabolites of nitrogen (II) oxide were determined. the concentration of diene conjugates (DC) and triene conjugates (TC) was evaluated by the method based on the fact that the extracted heptane-isopropyl hydroperoxide mixture had an appropriate absorption maximum: $d C$ at a wavelength of $232 \mathrm{~nm}$; TK at a wavelength of $275 \mathrm{~nm}$ [18]. The total nitric oxide metabolites in blood plasma: nitrite anion $\left(\mathrm{NO}_{2}{ }^{-}\right)$and nitrate anion $\left(\mathrm{NO}_{3}{ }^{-}\right)$, were determined by photometry using a Gray reagent (sulfanilamide solution and $\mathrm{N}$-naphthyl ethylenediamine dihydrochloride in $30 \%$ glacial acetic acid), which was used as a color reagent 
giving raspberry coloring in the presence of nitrogen oxide metabolites in a liquid [19]. the method of determining the concentration of TBA-active products consisted in the ability of malonic dialdehyde to interact with tiobarbituric acid in an acidic medium to form a colored complex which intensity is adequate to the content of TBA-active products [20]. The results were statistically analyzed by means of nonparametric indexes [21]. the data were presented in the arithmetic mean $(M) \pm$ standard deviation of the mean value $(m)$ for a specific number of the animals $(n)$. Changes were considered statistically significan at $p<0.05$. excel 2010 (Microsoft Corporation) and Statistica 10.0 (StatSoft, USA) software were used.

\section{Results}

These studies were performed in accordance with the suggested and patented patterns for experimental periodontitis [22], which presented the influence of bacterial and immune disorders on the mechanisms of inflammation development in periodontal complex. the study of experimental periodontitis is associated with the fact that this type and values of bacterialimmune infl mmation has not investigated before.

The results of the research proved that in the early period of inflammation development in periodontal complex, which included the period from the $1^{\text {st }}$ to the $7^{\text {th }}$ day of the experiment, there was an excessive accumulation of lipid peroxidation products in serum, as evidenced by increased concentration of DC (in 2.20 times, $p<0.01$ ) and TC (in 1.93 times, $p<0.01$ ) respectively, compared with the control group of experimental animals ( $t$ able 1, fig. 1). o $n$ the $14^{\text {th }}$ day of experimental periodontitis model, there was a significant decrease of $\mathrm{dC}$ (in 1.53 times, $p<0.01$ ) and TC (in 1.52 times; $p<0.01$ ) in serum compared to the group of animals studied on the $7^{\text {th }}$ day of the experiment, but these indices were higher than those of the intact animal group (in 1.44 times, $p<0.01$ and by 1.26 times, $p<0.01$, respectively).

In the further observation, on the $30^{\text {th }}$ day of inflammatory process development in the tissues of periodontal complex, the content of DC in blood serum slightly increased in comparison with the indices on the $7^{\text {th }}$ day, but the data were statistically insignificant ( $p>0.05)$, but on the $14^{\text {th }}$ day this index increased in 1.53 times $(p<0.01)$. When comparing it with the indices of the control group, it was found out that the content of this metabolite in serum was significantly higher (in 2.21 times, $\mathrm{p}<0.01$ ).

The content of triene conjugates changed the same during the period of monitoring, however, the increase in their concentration in blood serum was less significa $t$ - in 1.53 times $(p<0.01)$, compared with the indices on the $14^{\text {th }}$ day, and in 1.94 times $(p<0.01)$, compared with the control group. When comparing them with the results of the group of animals with experimental periodontitis on the $7^{\text {th }}$ day of the experiment, the changes were found to be statistically insignificant $(p>0.05)$

When determining the ratio of DK/TC content (Table 2) in blood serum, it was proved that that index significantly increased on the $7^{\text {th }}$ day of the study (in 1.15 times; $p<0.01$ )

Table 1. Concentration of diene and triene conjugates in serum of the rats in different periods of experimental periodontitis $(\mathrm{M} \pm \mathrm{m})$

\begin{tabular}{|c|c|c|c|c|}
\hline form of experiment & $\begin{array}{c}\text { duration of experiment } \\
\text { (days) }\end{array}$ & $\begin{array}{c}\text { Number of } \\
\text { animals }\end{array}$ & $\begin{array}{c}\mathrm{DC}, \\
\text { conditioned, units } / \mathrm{ml}\end{array}$ & $\begin{array}{c}\text { TC, } \\
\text { conditioned, } \\
\text { units } / \mathrm{ml} \\
\end{array}$ \\
\hline Control, intact animals & - & 10 & $2.383 \pm 0.071$ & $2.756 \pm 0.022$ \\
\hline \multirow{3}{*}{ Animals with periodontitis } & 7 & 8 & $\begin{array}{c}5.250 \pm 0.242 \\
\mathrm{p} 1<0,01\end{array}$ & $\begin{array}{c}5.310 \pm 0.187 \\
\mathrm{p} 1<0,01\end{array}$ \\
\hline & 14 & 8 & $\begin{array}{c}3.431 \pm 0.089 \\
\text { p1<0.01 } \\
\text { p2<0.01 }\end{array}$ & $\begin{array}{c}3.485 \pm 0.107 \\
p 1<0.01 \\
p 2<0.01\end{array}$ \\
\hline & 30 & 8 & $\begin{array}{c}5.266 \pm 0.141 \\
\text { p1<0.01, } \\
\text { p2>0.05, } \\
\text { p3<0.01 }\end{array}$ & $\begin{array}{c}5.338 \pm 0.140 \\
\text { p1<0.01, } \\
\text { p2>0.05, } \\
\text { p3 }<0.01\end{array}$ \\
\hline
\end{tabular}

Notes: $p 1$ - statistical significance of differences relative to the intact animals;

p2 - statistical significance of differences relative to the animals with experimental periodontitis on the $7^{\text {th }}$ day of the research; p3 - statistical significance of differences relative to the animals with experimental periodontitis on the $14^{\text {th }}$ day of the research. 


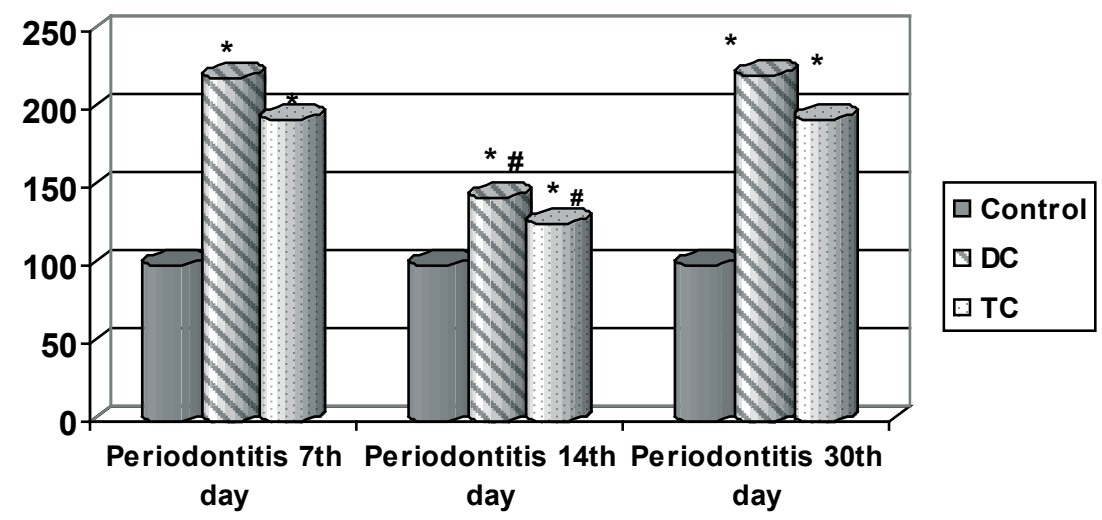

fig. 1. Changes in the indices of lipid peroxidation in rats' serum in the experimental periodontitis followup (\% of the control).

Notes: * - statistically significant differences relative to the intact animals $(p<0.01)$;

\# - statistically significant differences relative to the animals with periodontitis on the $7^{\text {th }}$ day of the experiment $(p<0.01)$;

- - statistically significant differences relative to the animals with periodontitis on the $7^{\text {th }}$ day of the experiment $(p>0.05)$;

${ }^{\circ}$ - statistically significant differences relative to the animals with periodontitis on the $14^{\text {th }}$ day of the experiment $(p<0.01)$.

compared to the control group and remained on the same level throughout the duration of the experiment: it was higher on the $14^{\text {th }}$ (in 1.16 times, $p<0.01$ ) and on the $30^{\text {th }}$ day (in 1.15 times, $p<0.01$ ) of the indices of the intact animals. When comparing the same ratios in the rats at different periods of the experiment, in particular on the $7^{\text {th }}, 14^{\text {th }}, 30^{\text {th }}$ days, the differences were statistically insignificant $(p<0.05)$.

As a result of the study of the main indices of lipid peroxidation - the content of $\mathrm{t} B$-active products, significant changes were also evidenced (Table 3). In particular, it was found out that on the $7^{\text {th }}$ day of experimental periodontitis development in the rats, this serum level was higher in 4.22 times $(p<0.01)$ compared to the control group.

On the $14^{\text {th }}$ day of the experimental periodontitis model, a gradual decrease in the level of TBA-active products (in 1.34 times, $p<0.01$ ) was evidenced in blood serum in comparison with the group of animals with inammatory process in periodontal tissues on the $7^{\text {th }}$ day of the experiment, but these indices were still increased compared to the intact group of animals (in 3.16 times, $p<0.01$ ), that proved a signicant activation of free radical lipid oxidation processes during the entire period of inflammation development. The studies on the $30^{\text {th }}$ day of the experiment proved that the content of TBA-active products in serum gradually decreased (in 1.49 times, $p<0.01$ and in 1.11 times, $p<0.01$ ) respectively, compared to the groups of animals with experimental periodontitis on the $7^{\text {th }}$ and $14^{\text {th }}$ days of the experiment. at the same time, it was higher (in 2.84 times, $p<0.01$ ) than in the intact group of white rats (Fig. 2).

at the early stage of experimental periodontitis development, that is on the $7^{\text {th }}$ day, there was a signicant increase in the content of nitric oxide metabolites ( $\mathrm{no}_{2}{ }^{-}+\mathrm{no}_{3}{ }^{-}$), which were classied as unstable products of free radical oxidation in serum (in 6.86 times, $p<0.01$ ), but on the $14^{\text {th }}$ day this index changed

Table 2. Correlation of diene and triene conjugates in serum of the rats in different periods of experimental periodontitis development $(\mathrm{M} \pm \mathrm{m})$

\begin{tabular}{|l|c|c|c|c|}
\hline \multicolumn{1}{|c|}{ form of experiment } & Control, intact animals & \multicolumn{3}{c|}{ Animals with periodontitis } \\
\hline d uration of experiment (days) & - & 7 & 14 & 30 \\
\hline Number of animals & 10 & 8 & 8 & 8 \\
\hline DC / TC & $0.86 \pm 0.03$ & $0.99 \pm 0.02$ & $1.00 \pm 0.04$ & $0.99 \pm 0.01$ \\
& & $p 1<0.01$ & $\begin{array}{c}p 1<0.01, \\
p 1<0.01, \\
p 2>0.05 \\
\text { p2 }>0.05 \\
\text { p3 }>0.05\end{array}$ \\
\hline
\end{tabular}

Notes: $p 1$ - statistically significant differences relative to the intact animals;

p2 - statistically significant differences relative to the animals with experimental periodontitis on the 7th day of the research; p3 - statistically significant differences relative to the animals with experimental periodontitis on the 14th day of the research. 


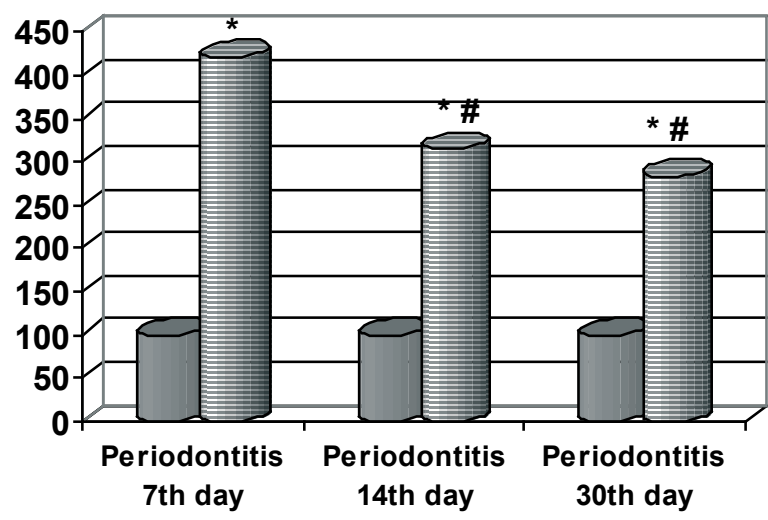

\begin{tabular}{|l|}
\hline$\square$ Control \\
$\square$ TBA-active products
\end{tabular}

fig. 2. Changes in the indices of $\mathrm{t} \mathrm{Ba-active} \mathrm{products} \mathrm{in} \mathrm{rats'} \mathrm{serum} \mathrm{in} \mathrm{the} \mathrm{experimental} \mathrm{periodontitis} \mathrm{follow-}$ up (\% of the control).

Notes: * - statistically significant differences relative to the intact animals $(p<0.01)$;

\# - statistically significant differences relative to the animals with periodontitis on the $7^{\text {th }}$ day of the experiment $(p<0.01)$;

${ }^{\circ}$ - statistically significant differences relative to the animals with periodontitis on the $14^{\text {th }}$ day of the experiment $(p<0.01)$.

reversely, that is it decreased (in 1.31 times, $p<0.01)$ compared with the animals on the $7^{\text {th }}$ day of the experiment, but was increased compared to the intact group of animals (in 5.25 times, $\mathrm{p}<0.01$ ) (Table 3, Fig. 3).

Characterizing the changes in the content of products of metabolism of nitric oxide in blood serum of the experimental animals with periodontitis, it should be noted that this active form of oxygen on the $30^{\text {th }}$ day of the experiment along with the lipoperoxidation indices of previous studies also signicantly increased (in 3.64 times, $p<0.01$ ) compared to the results of the animals of control group. However, the data were lower than those in rats on the $7^{\text {th }}$ (in 1.88 times, $p<0.01$ ) and $14^{\text {th }}$ days (in 1.44 times, $p<0.01)$ respectively.

\section{Discussion}

introduction of complex mixtures of microorganisms diluted in egg protein into periodontal tissues caused hyperergic inam matory process with signicant changes in soft tissue of lower jaw accompanied by edema and hyperemia of mucous membrane and the manifestations were the same as the changes in humans [23]. Inflammatory process in periodontal tissues was accompanied by cellular inltr ation of surrounding tissues and destructive changes in periodontal complex [24, 25].

The obtained data proved that generation of active forms of oxygen at a suciently high level, activation of free radical lipid oxidation were present during the entire period of

Table 3. The content of TBA-active products and metabolites of nitrogen (II) oxide (NO2-+NO3-) in serum of the rats in different periods of experimental periodontitis development $(\mathrm{M} \pm \mathrm{m})$

\begin{tabular}{|c|c|c|c|l|}
\hline \multirow{2}{*}{ form of experiment } & $\begin{array}{c}\text { duration of experiment } \\
\text { (days) }\end{array}$ & $\begin{array}{c}\text { Number of } \\
\text { animal }\end{array}$ & $\begin{array}{c}\text { TBA-active products, } \\
\mathrm{mcmol} / \mathrm{l}\end{array}$ & $\begin{array}{c}\text { no 2-+no 3-, } \\
\mathrm{mcmol} / \mathrm{l}\end{array}$ \\
\hline Control, intact animals & - & 10 & $2.555 \pm 0.092$ & $0.028 \pm 0.001$ \\
\hline \multirow{3}{*}{ Animals with periodontitis } & 7 & 8 & $\begin{array}{c}10.774 \pm 0.122 \\
\mathrm{p} 1<0.01\end{array}$ & $\begin{array}{l}0.192 \pm 0.006 \\
\mathrm{p} 1<0.01\end{array}$ \\
\cline { 2 - 5 } & 14 & 8 & $\begin{array}{c}8.066 \pm 0.143 \\
\mathrm{p} 1<0.01, \\
\mathrm{p} 2<0.01\end{array}$ & $\begin{array}{l}0.147 \pm 0.003 \\
\mathrm{p} 1<0.01, \\
\mathrm{p} 2<0.01\end{array}$ \\
\cline { 2 - 5 } & & 8 & $\begin{array}{l}7.255 \pm 0.103 \\
\mathrm{p} 1<0.01, \\
\mathrm{p} 2<0.01, \\
\mathrm{p} 3<0.01\end{array}$ & $\begin{array}{l}0.102 \pm 0.002 \\
\mathrm{p} 1<0.01, \\
\mathrm{p} 2<0.01, \\
\mathrm{p3}<0.01\end{array}$ \\
\hline
\end{tabular}

Notes: $p 1$ - statistically significant differences relative to the intact animals;

p2 - statistically significant differences relative to the animals with experimental periodontitis on the 7th day of the research; p3 - statistically significant differences relative to the animals with experimental periodontitis on the 14th day of the research. 


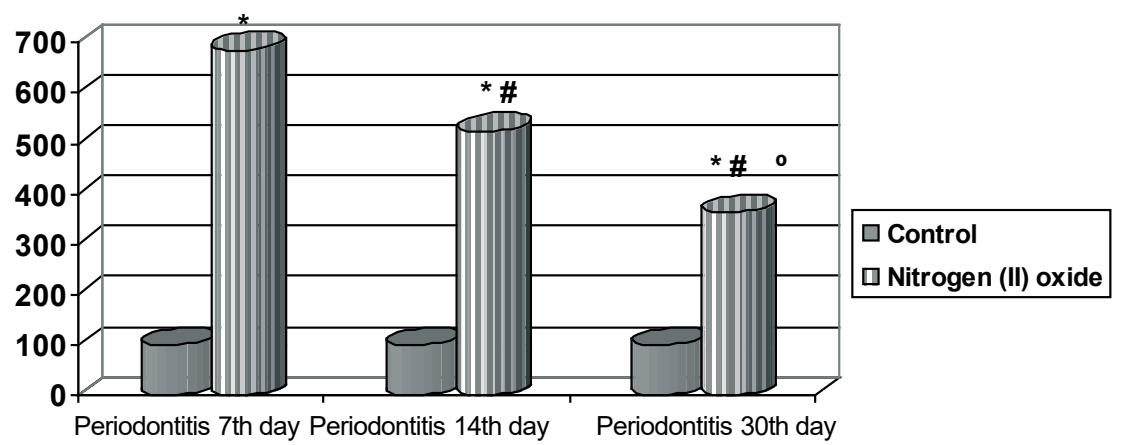

fig. 3. Changes in the indices of metabolites of nitrogen (II) oxide in rats' serum in the experimental periodontitis follow-up (\% of the control).

Notes: * - statistically significant differences relative to the intact animals $(p<0.01)$;

\# - statistically significant differences relative to the animals with periodontitis on the $7^{\text {th }}$ day of the experiment $(p<0.01)$;

${ }^{\circ}$ - statistically significant differences relative to the animals with periodontitis on the $14^{\text {th }}$ day of the experiment $(p<0.01)$.

inammatory reaction development, but the highest degree was during the peak of the inammatory process that corresponded to a more severe clinical picture in this group of animals. In a later period of periodontitis, despite a slight decrease in the intensity of I PO, a complete reduction of the inamed process in periodontal tissues did not take place, which may point to its chronicity.

the indices of lipid peroxidation activity: the content of TBA-active products in serum proved that irrespective of the period of their study, during the development of bacterial-immune experimental periodontitis, the formation and accumulation of intermediate toxic products of lipid peroxidation in serum took place at different stages of its chain branching. also, the inam matory reaction in periodontal complex in the acute period of development became a source of formation of reactive oxygen species, which were capable of triggering a cascade of free radical processes involving NO-radical metabolites. active form of oxygen on the $30^{\text {th }}$ day of the experiment proved the continuation of no generation, the enhancement of free radical processes activity and the disturbance of dynamic equilibrium with the antioxidant defense system.

\section{Conclusions}

the inammatory process with bacterialimmune component in periodontal complex is accompanied by increase of lipid peroxidation and nitric oxide metabolites in the blood serum that affects the course and completion of the inammatory pr ocess.

a signicant increase of diene and triene conjugates level and TBA-active products in blood serum in the acute period (on the $7^{\text {th }}$ day of the experiment) and a temporary decrease on the $14^{\text {th }}$ day, as well as further increase on the $30^{\text {th }}$ day of the experiment evidence the increased generation of reactive oxygen species and their derivates for the entire period of inammation de velopment.

the preservation of increased lipid peroxidation and nitric oxide metabolites in blood serum of the experimental animals with acute periodontitis conduce to enhance of alteration and delayed healing that result in its sequel into chronical periodontitis.

\section{РОЛЬ АКТИВНИХ ФОРМ КИСНЮ ТА НІТРОГЕНУ У РОЗВИТКУ ЕКСПЕРИМЕНТАЛЬНОГО ПАРОДОНТИТУ}

А. $€$. Демкович

ТЕРНОПІЛЬСЬКИЙ ДЕРЖАВНИЙ МЕДИЧНИЙ УНІВЕРСИТЕТ IMЕНІ І. Я. ГОРБАЧЕВСЬКОГО, ТЕРНОПІЛЬ, УКРАЇНА

Вступ. Розвито оксидативного стресу є одним з пускових механізмів патогенезу ушкодженння пародонту. Активні форми кисню та нітрогену здатні викликати пошкодження клітини, так само як і кінцеві продукти перекисного окислення ліпідів, включаючи ненасичені альдегіди та інші метаболіти.

Мета дослідження полягала у визначенні ролі активних форм кисню та нітрогену та накопичення продуктів перекисного окислення ліпідів у формуванні хронічного запального процесу в пародонті.

Методи. Експериментальний пародонтит моделювали у тварин шляхом введення складних сумішей мікроорганізмів, розведених в яєчному білку. Активність вільнорадикальних процесів у сироватиі крові оцінювали за вмістом дієнових та трієнових кон'югатів, ТБК-активних продуктів та метаболітів оксиду азоту (NO2- та $\mathrm{NO}^{3-}$ ) на 7-у, 14-у та 30-у доби експерименту.

Результати. Генерація активних форм кисню забезпечує значну тривалість запального процесу. Тому типова динаміка процесів перекисного окислення ліпідів у розвитку та перебізі експериментального періодонтиту викликає значний інтерес. Результпти нашого дослідженння запального процесу з бактеріально-імунною складовою в періодонтальному комплексі щурів довело важливу роль накопичення продуктів перекисного окислення ліпідів і метаболітів оксиду азоту в сироватці крові. 
Висновки. Підвищений рівень продуктів перекисного окислення ліпідів та метаболітів оксиду азоту в сироватиі крові експериментальних тварин з гострим парродонтитом сприяює поглибленню патологічного процесу та уповільнює загоєння, що призводить до розвитку хронічного перебігу захворювання.

КЛЮЧОВІ СЛОВА: пародонтит; метаболіти оксиду азоту; ТБК-активні продукти; дієнові кон'югати; трієнові кон'югати.

\section{References}

1. Borisenko A. Periodontal disease. Kyiv: Medicine; 2013.

2. Dimi ova A, Kolenko Y. Evaluating the effectiveness of various immunomodulators in complex treatment generalized periodontitis in young adults (18-25 years). J Modern Dentistry. 2013;2:38-9.

3. Zabolotniy, Markov A, Shilivsky I. Generalized periodontitis. Lviv: Galdent; 2011.

4. Tamaki N, Takaki A, Tomofuji T, Endo Y, Kasuyama K, Ekuni D. Stage of hepatocellular carcinoma is associated with periodontitis. J Clin Periodontol. 2011;38:1015-20. doi: 10.1111/j.1600-051x. 2011.01777.x.

5. erkaik MJ, Busscher HJ, Rustema-Abbing $M$, Slomp AM, Abbas F, van der Mei HC. Oral biofilm models for mechanical plaque removal. Clin Oral Invest. 2010;14:403-9. doi: 10.1007/s00784-0090309-x.

6. Kaplan JB. Biofilm dispersal: mechanisms, clinical implications and potential therapeutic uses. J Dent Res. 201 0;89:205-18. doi: 10.1177/ 0022034509359403

7. Arimatsu K, Yamada H, Miyazawa H, Minaqawa T, Nakajima M, Ryder MI, et al. Oral pathobiont induces systemic inflammation and metabolic changes associated with alteration of gut microbiota. Sci Rep. 2014;6(4):4828. doi: 10.1038/srep04828.

8. Demkovych A, Bondarenko YU, Hasiuk PA. Oxidative modification of proteins in the process of experimental periodontitis development. Interventional Medicine and Applied Science. 2017;9(4): 218-21. doi: 10.1556/1646.9.2017.28.

9. Srivastava N, Nayak PA, Rana S. Point of Care A Novel Approach to Periodontal Diagnosis - A Review. J Clin diagn Res. 2017;11(8):Ze01-Ze06. doi: 10.7860/JCDR/2017/26626.10411.

10. Gross AJ, Paskett KT, Cheever VJ, Lipsky MS. Periodontitis: a global disease and the primary care provider's role. Postgrad Med J. 2017;93(1103):560-5. doi: 10.1136/postgradmedj-2017-134801.

11. Butyugin I, Kornilov N, Abramov O. Comparative analysis of the effectiveness of topical application of antioxidants in the treatment of chronic generalized periodontitis. J Dentistry. 2013;92:31-4.

12. Sahiner UM, Birben E, Erzurum S, Sackesen C, Kalayci O. Oxidative stress in asthma. World allergy organ J. 2011;4( 10):151-8. doi: 10.1097/ WOx. 0b013e318232389e.

13. Dahia P, Kamal R, Gupta R, Bhardawai R, Chaudhary K, Kaur S. Reactive oxygen species in periodontitis. Indian Soc Periodontol. 2013;17(4):4116. doi: 10.4103/0972-124x.11830

14. Melnichuk G, Kostyuk I. The evolution of lipid peroxidation and antioxidant protection in the blood serum of children with permanent teeth granulating periodontitis and chronic heightened course, influenced treatment. J Modern Stomatology. 2012;3:25-28.

15. Nemec A, Pavlica Z, Petelin M, ossley DA, Sentjurc M, Jerin A, Erzen D, Zdovc I, Hitti T, Skaleric U. Systemic use of selective iNOS inhibitor 1400W or non-selective NOS inhibitor L-NAME differently affects systemic nitric oxide formation after oral Porphyromonas gingivalis inoculation in mice. Arch Oral Biol. 2010;55(7):509-14. doi: 10.1016/j. archoralbio.2010.04.003.

16. Nemec A, Pavlica Z, ossley DA, Sentjurc M, Jerin A, Erzen D, Vrecl M, Majdic G, Zdovc I, Petelin M, Skaleric U. Chronic ingestion of Porphyromonas gingivalis induces systemic nitric oxide response in mice. Oral Microbiol Immunol. 2009;24:204-10. doi: 10.1111/j.1399-302x.2008.00496.x.

17. Demkovych AYe, Bondarenko YuI. Pathogenetic basis periodontitis modeling in rats. Achiev of Clin and Exper Med. 2015;1(22);54-57.

18. Buzlama VS, Retskiy MI, Meshcheryakov NP. A methodical manual on studying the processes of lipid peroxidation and the system of antioxidant protection of animal oganism. Voronezh: Medicina; 1997.

19. Sklyarov O, Fedorovych IP, Korobov VM. Changes in NO2 concentration in biological fluids in diseases of stomach cancer. Med Chemistry. 2004;6(3):55-7.

20. Andreeva LI, Kozhemyakin LA, Kishkun AA. Modification of the method for determination of lipid peroxides in the test with thiobarbituric acid. Lab Case. 1988;11:41-3.

21. Berger RL, Casella G. Statistical Inference $2^{\text {nd }}$ ed. Florida: Duxbury Press; 2001.

22. Demkovych AY, Bondarenko YI, inventor; I. Horbachevsky Ternopil State Medical Univ., assignee. Pathogenetic basis periodontitis modeling in rats. Ukraine patent 82388 u201303000. 2013 Jul 25.

23. D ovych A. The necrotic-apoptotic changes in blood mononuclear phagocytes in the experimental bacterial-immune periodontitis development. World of Medicine and Biology. 2018;No.1(63):120-122. doi: 10.26.724/2079-83342018-1-63-120-122.

24. Bullon P, Cordero MD, Quiles JL, RamirezTortosa Mdel C. Autophagy in periodontitis patients and gingival fibroblasts: unraveling the link between chronic diseases and inflammation. BMC Med. 2012;17:10-122. doi: 10.1186/1741-7015-10-122.

25. Jin CQ, Dong HX, Cheng PP, Zhou JW, Zheng BY, Liu F. Antioxidant status and oxidative stress in patients with chronic ITP. Scand J Immunol. 2013;77:482-7. doi: 10.1111/sji.12048.

Received: 2018-04-06 